UDC 81'322.3:81'276.6:62

DOI https://doi.org/10.32999/ksu2663-2691/2020-81-9

\title{
NEGATIVE MODAL VERB CONSTRUCTIONS IN THE TEXT CORPORA OF SCIENTIFIC AND TECHNICAL DISCOURSE
}

\author{
Borisenko Tatyana Ilinichna, \\ Candidate of Philological Sciences (PhD), Associate Professor, \\ Associate Professor at the Department of Foreign Languages \\ Odessa National Polytechnic University \\ tanya47@gmail.com \\ orcid.org/0000-0002-9839-1761
}

Tsynova Maryna Viktorovna, Candidate of Historical Sciences (PhD), Associate Professor, Associate Professor at the English Language Department National University "Odessa Maritime Academy" marinatsinovaya@gmail.com orcid.org/0000-0003-2633-8416

The purpose of the article is to describe the results of the analysis of modal verb constructions (MVCs) used with negative not in the texts of scientific and technical discourse. Although modal verb constructions are already presented both in classical textbooks and research studies in sufficient detail but for the first time they are examined on the basis of technical text corpora, in this article - "Heat Engineering", "Automotive" and "Electrical Engineering".

Methods. The following methods were used in the article: continuous sampling for compiling the text corpora; expert assessment for the correct attribution of a particular lexical unit to a specific area of scientific discourse or the lexical layer; "quantitative" mathematics to summarize, compare and generalize the data obtained.

Results. The results of a quantitative analysis of negative modal verb constructions showed that their distribution across the text corpora of three specialties is uneven: "Heat Engineering" contains 50 units, "Automotive" - 30, "Electrical Engineering" - 27 MVCs, but only 8 units that were found practically in all corpora entered the list considered. An analysis of the lexical meanings of the notional verbs (the second constituent of MVC) included in the MVCs was also made to find out if there is a dependence of intralinguistic factors on extralinguistic ones in the MVCs.

Conclusions. The study shows that there is a direct relationship between extra linguistic factors - the existence of certain processes, objects and phenomena of a particular technical field, and intralinguistic characteristics - lexical meanings (common, general scientific and terminological) of notional verbs that are included in negative MVCs. It was determined that in the texts of the specialty "Heat Engineering" these MVCs do not directly participate in describing the operation of technical objects or production processes, since notional verbs have common or general scientific meanings. But in the automotive industry texts, the lexical meanings of notional verbs refer mainly to the terminological layer, which shows their significant role in the direct description of objects, phenomena and processes in this technical field. From the viewpoint of the lexical meanings the notional verbs in negative MVCs in the specialty "Electrical Engineering" texts, they occupy an intermediate position between "Heat Engineering" and "Automotive", i.e. here along with the units having general scientific meanings there are several terms.

Key words: notional verb, quantitative characteristics, frequency of usage, lexical meaning, term system.

\section{НЕГАТИВНІ МОДАЛЬНІ ДІССЛІВНІ КОНСТРУКЦЇ̈ В ТЕКСТОВИХ КОРПУСАХ НАУКОВО-ТЕХНІЧНОГО ДИСКУРСУ}

\author{
Борисенко Тетяна Іллівна, \\ кандидат філологічних наук, дочент, \\ доцент кафедри іноземних мов \\ Одеського національного політехнічного університету \\ tanya47@gmail.com \\ orcid.org/0000-0002-9839-1761
}

\author{
Цинова Марина Вікторівна, \\ кандидат історичних наук, дочент, \\ доцент кафедри англійської мови \\ Національного університету «Одеська морська академія» \\ marinatsinovaya@gmail.com \\ orcid.org/0000-0003-2633-8416
}

Мета статті - опис результатів аналізу модальних дієслівних конструкцій (МДК), використовуваних із запереченням $n o t$ у текстах науково-технічного дискурсу. Хоча модальні дієслівні конструкції вже досить докладно представлені як у класичних підручниках, так і наукових дослідженнях, але на матеріалі технічних текстових корпусів, у нашій статті - «Теплотехніка», «Автомобілебудування», «Електротехніка»- вони розглядаються вперше. 
Методи. У статті використовувалися такі методи: суцільної вибірки для створення текстових корпусів; експертної оцінки для коректного віднесення тієї чи іншої лексичної одиниці до певної галузі наукового дискурсу або лексичному шару; «Кількісної» математики для підсумовування, зіставлення й узагальнення отриманих даних.

Результати. Результати кількісного аналізу негативних модальних дієслівних конструкцій показали, що їх розподіл за текстовими корпусами трьох спеціальностей є нерівномірним: «Теплотехніка» - 50 одиниць, «Автомобілебудування» - 30, «Електротехніка» - 27 МДК, у розглянутий список було введено тільки 8 одиниць, які зустрічалися практично у всіх текстах. Був також проведений аналіз лексичних значень повнозначних дієслів, що входять до МДК, щоб дізнатися, чи існує в МДК залежність інтралінгвістичних факторів від екстралінгвістичних.

Висновки. Дослідження показало, що існує прямий зв'язок між екстралінгвістичними факторами - існуванням певних процесів, об'єктів і явищ тієї чи іншої технічної області, й інтралінгвістичними характеристиками - лексичними значеннями (загальновживаними, загальнонауковими і термінологічними) повнозначних дієслів, що входять до негативних МДК. Було визначено, що в текстах спеціальності «Теплотехніка» ці МДК не беруть безпосередньої участі під час опису експлуатації технічних об’ єктів або виробничих процесів, оскільки повнозначні дієслова мають загальновживані або загальнонаукові значеннями. Але в текстах iз автомобілебудування лексичні значення повнозначних дієслів належать здебільшого до термінологічного шару, що показує їх значну роль у безпосередньому описі об'єктів, явищ і процесів цієї сфери техніки. 3 погляду лексичних значень повнозначних дієслів у негативних МДК у текстах за фахом «Електротехніка» вони займають проміжне положення між «Теплотехніка» й «Автомобілебудування», тобто тут, поряд із одиницями з загальнонауковими значеннями, наявні і кілька термінів.

Ключові слова: повнозначні дієслова, кількісні характеристики, частота вживання, лексичне значення, терміносистема.

\section{Introduction}

A detailed description of the most diverse aspects of modal verb constructions in the English language can be found both in classical textbooks and in linguistic literature describing the scientific studies related to this issue. If we turn to theoretical and applied research at the end of the last century then it can be noted that modal constructions were considered mainly from the point of view of statistical linguistics for assigning units of these constructions to one or another type of the discourse (Budkova, 2012; Buntina, 1979).

At present either the very notion of modality is in the focus of attention as a cognitive parameter of these grammatical units or syntactic, semantic and pragmatic sides of modal verbs are described from the standpoint of comparative linguistics (Grebneva, 2004; Umatova, 2014; Mukhometzyanova, 2007; Samoilova, 2008; Olenchuk, 2012). However, reviewing analysis of linguistic literature did not reveal any dissertation or article based on the text corpora of scientific and technical communication. Therefore, the purpose of this article is to describe the results of the analysis of modal verb constructions (MVCs) used with negative not in the texts of scientific and technical discourse.

Achieving this goal implies fulfilling the following tasks:

- compilation of text corps that may become a basis for future research;

- extraction of modal verb constructions with negative not from the texts;

- comparing modal units with this particle, found in different technical specialties corpora;

- determination of the peculiarities in usage of modal verb constructions with not in various text corpora.

The material for this article was taken from the text corpora of three sublanguages that are referred to scientific discourse and serve the following fundamental areas of science and technology - Automotive, Heat Engineering and Electrical Engineering, the total volume of corpus analyzed makes 300 thousand tokens. The sources from where the information was taken were texts from scientific journals published in the UK and USA: "IEEE Transactions on Power Apparatus and Systems"; "Power Engineering", "Power", "Automotive News"; "Combustion", "Control and Optimization"; "Machine Design", "Machinery and Production Engineering"; "Automotive Engineer". As you can see, the subjects of all three corpora have no common characteristics which allows the authors to draw generalizing conclusions that can be correct for almost any field of knowledge included in the scientific and technical discourse.

The following methods were used to accomplish the tasks: the continuous sampling method for compiling text bodies; expert assessment method for correct assigning a particular lexical unit to a specific area of scientific discourse; "quantitative" mathematics for summing, comparing and summarizing the data.

\section{Negative MVCs as a phenomenon of the text}

First of all among the modal units that are considered to be modal verbs in English it was necessary to determine the ones which can be the object of the future research. In accordance with the traditional point of view the group of modal verbs includes the following ones - can / could, may / might, must, ought, shall / should, will / would, dare, need. These verbs in their lexical meaning and a number of structural features (the ability to be connected only with the infinitive, the absence of non-personal forms, etc.) differ from the notional verbs and perform an auxiliary function. Some linguists add the verbs to have and to be to this group (Dolgopolova, 1961; Strang 1962).

However not all of the indicated modal verbs are found in the selected text corpora, and it primarily concerns modal ones which have the negative particle not. For example, such verbs as dare, need, shall / should, will / would, ought are not represented. The verbs to be, must occur at such a low frequency level that they were not included in the group of analyzed modal verbs. Thus the list of modal verbal constructions with a negative particle not used for analysis included the following ones: can / could; may / might; to have.

It should be noted that negative modal verb constructions are not characterized by a very high frequency of occurrence in the texts of technical specialties, their quantitative values are quite low. However the problem of studying this type of construction itself is of interest from the point of view of the interaction of extra linguistic and intra linguistic factors, i.e. the influence of the very fact of the existence of various technical objects and their activities on the appearance of a particular phenomenon in the language. 
At the first stage of the analysis, we considered the quantitative distribution of modal verbs with a negative particle not that were found in the texts. It was determined that the distribution of negative modal verb constructions in the text corpora is uneven. The largest number of them is found in the text corpus "Heat Engineering" -50 units; the second place is taken by the text corpus "Automotive" - 30 units; and finally 27 modal units of this type were found in the "Electrical Engineering" corpus. Thus the total number of negative MVCs is 107 units. Below there will be given a list of this type of MVCs in descending order of frequency of their occurrence in the texts of all three specialties. Not all negative MVCs will be presented in the list, but only those ones that were found in almost all text corpora. There are 8 units of MVCs .

\section{The negative MVC distribution around the corpora}

So as it has already been mentioned the largest number of negative MVCs was found in the texts on specialty "Power Engineering". The following structures which function in other text corpora as well were selected from them: 1) cannot + passive indefinite infinitive -15 units (e.g. cannot be measured, cannot be powered); 2) cannot + active indefinite infinitive - 12 (e.g. cannot connect, cannot contain; 3 ) may not + active indefinite infinitive -6 units (for example, may not discuss, may not verify); 4) may not + be + adjective -5 units (e.g. may not be independent, may not be single); 5) could not + active indefinite infinitive -4 units (e.g. could not determine, could not consist); 6) may not + passive indefinite infinitive -3 units (e.g. may not be permitted, may not be considered); 7) (does) not have + active indefinite infinitive -2 units (e.g. does not have to design); 8) could not + passive indefinite infinitive -1 unit (e.g. could not be operated).

If to consider the MVCs presented as examples then we can see that the main lexical meanings of the second constituents have common and general scientific meanings, a certain degree of terminology is noted in the MVC could not + passive indefinite infinitive and (does) not have + active indefinite infinitive. However the low usage frequency of the latter ( 1 and 2 MVCs) gives the reason to consider the usage of terms in these MVCs as being random. Thus, we can conclude that in the description of power engineering processes, phenomena and objects, negative MVCs are used. They are not related directly but indirectly to this field of technology through general reasoning or historical excursus. So, there is no necessity in negative MVCs that would have as main verbs the ones included in the terminology system of this specialty.

The text corpus of the specialty "Automotive" contains the following MVCs: 1) cannot + passive indefinite infinitive 7 units (e.g. cannot be driven, cannot be started); 2) cannot + active indefinite infinitive -7 units (e.g. cannot brake, cannot revolve); 3) may not + active indefinite infinitive -2 units (e.g. may not install, may not involve); 4) may not + be + adjective - is not used in the texts on "Automotive"; 5) could not + active indefinite infinitive - 4 units (e.g. could not effect, could not stop); 6) may not + passive indefinite infinitive - is not used in the texts on "Automotive"; 7) (does) not have + active indefinite infinitive -1 unit (e.g. does not have to move); 8) could not + passive indefinite infinitive -1 unit (e.g. could not be produced).

As one can see the number of negative MVCs has significantly decreased primarily due to the lack of units may not + be + adjective and may not + passive indefinite infinitive. The lexical meanings of the second constituent - a notional verb in MVCs of this specialty - show that the common meaning is observed only in may not + active indefinite infinitive; general scientific in could not + have passive indefinite infinitive and (does) not have + active indefinite infinitive. In other types of negative MVCs the second (notional) structural element has a terminological meaning. That means that the description of the processes, objects and phenomena in automotive requires (with a few exceptions) the presence of negative MVCs with the terms included which indicates that this type of MVCs plays a significant role in the creation, operation and regulation of these processes, objects and phenomena.

Modal verb constructions in the subject field "Electrical Engineering" are presented in the following way: 1) cannot + passive indefinite infinitive -9 units (e.g. cannot be calculated, cannot be connected); 2 ) cannot + active indefinite infinitive -4 units (e.g. cannot operate, cannot flow); 3) may not + active indefinite infinitive -4 units (e.g. may not remove, may not choose); 4) may not + be + adjective -4 units (e.g. may not be open, may not be short); 5) could not + active indefinite infinitive -1 unit (e.g. could not substitute); 6) may not + passive indefinite infinitive - 1 unit (e.g. may not be removed); 7) (does) not have + active indefinite infinitive - is not used in texts on electrical engineering; 8) could not + passive indefinite infinitive -1 unit (e.g. could not be set up).

The data presented show that, firstly, in contrast to the negative MVCs in the texts "Automotive" the list of constructions in the field "Electrical Engineering" excludes only one type of negative MVCs (in the texts on automotive - the two ones). This fact allows us to state that the description of the phenomena, objects and processes in the sphere of electrical engineering requires the usage of a wide variety of negative MVCs. Probably, in quantitative terms, their frequency values are small, but the qualitative characteristics (types) are presented very widely. The main lexical meaning presented in the notional verbs of negative MVCs is general scientific meaning, and some MVCs demonstrate examples of terminological meanings: 1) cannot be connected; 4) may not be open (open is a term in electrical engineering, it is used when describing an electrical circuit, "closed electrical circuit").

\section{Conclusions}

The results of text corpora study in three different fundamental areas of science and technology "Automotive", "Heat engineering" and "Electrical engineering" allow us to come to the following general conclusions about the features of negative modal verb constructions functioning in these fields.

1. Negative modal verb constructions are not used in the texts of these specialties quite often, their number is 107 units per 300 thousand tokens. Their distribution in the text corpora is uneven: 50 negative MVCs appear in the texts on "Heat Engineering", $30-1$ in the texts on "Automotive" and 27 - in the corpus "Electrical Engineering". But 8 types only were found in almost all corpora. 
2. An analysis of lexical meaning dependence of the notional verbs included in negative MVCs on extra-linguistic factors showed the following. Almost all notional verbs in the largest group of negative MVCs from "Heat Engineering" field have common or general scientific meanings which shows that their usage is indirectly related to the description of objects, processes and phenomena in this technical area. The group related to the specialty "Automotive" differs significantly from the group on the specialty "Heat Engineering". Firstly, there is a two-unit decrease in the number of MVCs, and secondly, the lexical meanings of the notional verbs relate mainly to the terminological layer, which shows their significant role in the direct description of objects, phenomena and processes in this technical field. The group of negative MVCs on the specialty "Electrical Engineering" is characterized by the absence of one unit in its list; in terms of the lexical meanings of the notional verbs it can be said that this group occupies an intermediate position between the two lists discussed above. Here along with the units with general scientific meanings several terms are present.

Further research is also planned to be carried out with modal verb constructions as objects of analysis and on the basis of the same material - the text corpora "Heat Engineering", "Automotive", and "Electrical Engineering". However MVCs will be considered together with various modifiers which are usually attached to them in the texts.

\section{Bibliography:}

1. Будкова С.С. Лексикографическое описание английской терминологии радиационных и плазменных технологий : автореф. дис. ... канд. филол. наук : 10.02.04. Омск, 2012. 24 с.

2. Бунтина Т.А. Взаимосвязь лексико-семантических и грамматических характеристик глагола в функциональном стиле : автореф. дис. ... канд. филол. наук : спец. 10.02.04. Киев, 1979. 26 с.

3. Гребнева О.В. Модальность необходимости в законодательных текстах Европейского Союза : автореф. дис. ... канд. филол. наук : 10.02.20. Казань, 2004. 20 с.

4. Уматова М.Б. Сравнительный анализ модальных глаголов в английском и узбекском языках. Молодой ученый. 2014. № 7. C. 641-642.

5. Мухометзянова Ю.В. Функционально-семантический аспект высказываний со значением возможности : автореф. дис. ... канд. филол. наук :10.02.19. Тверь, 2007. 20 с.

6. Самойлова Ю.А. Двойные и тройные сочетания модальных глаголов в языке равнинной Шотландии (скотс). Известия РГПУ им. А.И. Гериеена. 2008. Вып. № 73-1. С. 400-404.

7. Оленчук О.Г. Языковые средства репрезентации проблематической модальности : автореф. дис. .... канд. филол. наук : 10.02.19. Ижевск, 2012. 22 с.

8. Долгополова З.К. Модальные глаголы в английском языке: учебное пособие для студентов-филологов / Отв. Редактор Н.Ф. Иртеньева. Москва : Высшая школа, 1961. 86 с.

9. Strang B. Modern English Grammar. London: Edward Arnold, 1969. 264 p.

\section{References:}

1. Budkova S.S. (2012) Leksikograficheskoe opisanie angliyskoy terminologii radiatsionnykh i plazmennykh tekhnologiy: avtoref. dis. ... kand. filol. nauk: 10.02.04. Omsk. 24 p. [in Russian].

2. Buntina T.A. (1979) Vzaimosvyaz leksiko-semanticheskikh i grammaticheskikh kharakteristik glagola v funktsionalnom stile: avtoref. dis. ... kand. filol. nauk: spets. 10.02.04. Kiev. 26 p. [in Russian].

3. Grebneva O.V. (2004) Modalnost neobkhodimosti v zakonodatelnykh tekstakh Yevropeyskogo Soyuza: avtoref. dis.... kand. filol. nauk: 10.02.20. Kazan. 20 p. [In Russian].

4. Umatova M.B. (2014) Sravnitelnyy analiz modalnykh glagolov v angliyskom i uzbekskom yazykakh. Molodoy uchenyy. № 7. P. 641-642. [in Russian].

5. Mukhometzyanova Yu.V. (2007) Funktsionalno-semanticheskiy aspekt vyskazyvaniy so znacheniem vozmozhnosti: avtoref. dis. ... kand. filol. nauk:10.02.19. Tver. 20 p. [in Russian].

6. Samoylova Yu.A. (2008) Dvoynye i troynye sochetaniya modalnykh glagolov v yazyke ravninnoy Shotlandii (skots). Izvestiya RGPU im. A.I. Gertsena. Vyp. № 73-1. P. 400-404. [in Russian].

7. Olenchuk O.G. (2012) Yazykovye sredstva reprezentatsii problematicheskoy modalnosti: avtoref. dis. ... kand. filol. nauk: 10.02.19. Izhevsk. 22 p. [In Russian].

8. Dolgopolova Z.K. (1961) Modalnye glagoly v angliyskom yazyke: uchebnoe posobie dlya studentov-filologov / Otv. Redaktor N.F.Irteneva. Moscow : Vysshaya shkola. 86 p. [In Russian].

9. Strang B. Modern English Grammar. (1969) London: Edward Arnold. 264 p. 